Bastian Lange, Berlin / Anne von Streit, München

\title{
Governance of creative industries
}

\author{
A comparison of the characteristics and challenges in the software/games industry \\ in Munich and Leipzig
}

\begin{abstract}
The increasing acceptance of creative industries as a sphere of socio-economic activity gives rise to the question how this sector can be promoted appropriately. This paper comprises a theoretical discussion and an empirical analysis of different modes of governance at two contrasting locations in Germany, taking the example of the software/games industry sector. Specifically, we shall look both at formal and informal mechanisms of coordination. We explore to what extent the existing political-administrative support structures at the two selected locations are adapted appropriately to the internal organisation and the special characteristics of these sectors. Our results point to the difficulties in designing market-specific and location-specific strategies aimed at different environments. Finally, this paper aims to contribute to the understanding of how traditional political institutions can further adapt to the demand for more flexible governance, such as is needed by the creative industries.
\end{abstract}

Keywords: governance, creative industries, software/games industry, comparative methodology, networks, Leipzig, Munich

\section{Introduction}

In Germany, for a few years now, administrative representatives from economic development and cultural affairs have started to include the creative industries in their administrative portfolio (BMWi 2009a; b). This increasing acceptance of these rather fluid and fragile economies as a sphere of public and economic activity generates new questions regarding the policies needed to govern them adequately, for a number of reasons. Firstly, due to the increasing temporality and hybridisation of these new creative economies (GRABHER 2004) and the lasting scepticism toward these types of economy on the part of public authorities (GALLOWAY/DUNLOP 2007), the political administration has difficulties in inventing appropriate steering measures and policy approaches to support these economies. Secondly, various administrative as well as private agencies are searching for new and adequate forms of governance that range from 'hard' funding instruments (e.g. micro-credits) to 'soft' communicative structures to support the creative industries (e.g. LANGE et al. 2010). Thirdly, when the public administration engages with creative workers or vice versa, complex differences have come to the fore, mainly due to the use of different semantics, different professional habits, and various value systems that differ significantly with regard to e.g. service industries. For example, CAVES (2001) and HAunschiLd/ EICKHOF (2007) have pointed to the very notion that different ethics and cultural values guide cultural practices in economic fields.

The starting point for our discussion is the empirical observation that suitable existing support structures for this economy are in conflict with the style of work, the self-image and the scalar range of business interaction in the creative industries. It becomes obvious here that especially scalar disparities regarding timing and installation of support structures on the one hand conflict with the internal functioning of this type of economy on the other. Very often, this leads to a mismatch between e.g. public administration and creative workers and firms from creative industries.

Using the example of the software/games industry at two different locations, we want to ask how regionally-based governance measures can be empirically analysed in order to understand the fit or lack of fit between public institutions on one side and private companies from the cre- 
ative sectors on the other side when city regions decide to promote this sub-sector economically. The software and games industry provides a valuable case study as it contributes considerably to the overall growth of creative industries and has therefore recently caught the attention of public administrators aiming at including these industries in their remit (e.g. WALz/SEIBERT 2010; BMWi 2010).

\section{Research agenda and outline of the article}

The overall aim of the paper is to analyse governance structures within one sub-branch of the "creative industries" and to point to the difficulties in designing market-specific and locationspecific strategies aimed at promoting creative industries in general. In doing so, we shall look at both formal and informal mechanisms of coordination in terms of their scalar range, and we ask to what extent the political-administrative support structures at two selected locations, which offer these sectors a very different environment, are adapted to the internal organisation and the special characteristics of these sectors. By comparing two empirical case studies, this paper discusses the following research questions:

1. Which institutional stakeholders are active in promoting the software and games industry in Munich and Leipzig, and by which means (hierarchical governance?)

2. What level of self-organisation can be found in the software and games industries (what level of self-governance arises) at the two locations?

3. What kind of systemic frictions and conflicts arise out of multi-scalar governance approaches when looking at these two cases in Leipzig and Munich?

Firstly, on the basis of conceptual prerequisites, different modes of governance will be presented, highlighting different interests, and distinct logics of action, when promoting creative industries and their agents. Secondly, overall global market trends will be presented and a special focus will be directed at the two researched sites - Leipzig and Munich. The third part is concerned with our empirical case study at Leipzig and Munich by analysing different modes of governance and the various interests of public, intermediary and private stakeholders. Finally, we shall ask how local policies relating to location and economic assistance can be put in place at all, given the strongly global orientation of the software and games industry. The final results of the paper aim to contribute to the understanding of how traditional political institutions can further adapt to the demand for more flexible governance of the creative industries, which could also serve as a blueprint for context-oriented policy approaches for other sectors, and other fields of urban regional policies (PRATT 2009).

\section{Defining creative industries and governance}

\section{Creative industries}

The definition of creative industries is a contested one. Creative industries have been defined by branches and sectors (BMWi 2009a), by clusters (COOKE/LazZereTti 2008) or by their mesocategorical dimensions: for example, as social networks (VAN HEUR 2008), as creative scenes (LANGE 2005) or as innovative milieus (CREVOISIER 2004). While the definition as branches e.g. of design, architecture, music, fashion, as it has been applied in federal and municipal administration in Germany for the last few years, might be helpful for an understanding of the overall economic development of these sectors, only an in-depth research perspective enables us to understand the forms of internal structuring of local markets. That seems to be of great interest for academic research as well as for policy making, in order to enable understanding of the idiosyncratic as well as the distinctive nature of creativity-driven steering approaches adopted by public administration aiming at fostering urbanbased economies.

In the more recent past, mainly organisational and economic geography studies have approached creative industries by analysing organisational changes within and among mainly small and medium-sized enterprises (SCOTT 2006; NeFF et al. 2005; LANGe 2007; vON StREIT 2011). It was Grabher in particular who focused on the intra-organisational dimension of the emergent network-based project ecologies and their entrepreneurial as well as socio-spatial practices in these industries (DeFillipPI et al. 2007; GraBHER 2004). The euphoric discourse on creative industries nevertheless has also raised profound 
scepticism regarding its potential to be steered in a traditional manner (HESMONDHALGH/BAKER 2008; INDERGAARD 2009). Furthermore, several structural paradoxes have been detected that are inherent in creative industries and their entrepreneurial agents (BATHELT 2005; DeFILLIPPI et al. 2007; FIKIRKOCA 2007) which include: a) the need to reconcile tensions between the work ethos and human resource practices in creative and more routinised activities; and b) the need to balance the advantages of flexible and temporary organisation with the advantages of tight integration.

\section{Governance}

In political science, governance refers to new relationships between state and society that imply a blurring of traditional boundaries of governmental agency (JESSOP 1995; RHODES 1996). Urban-regional development is increasingly dependent on appropriate steering structures (FICHTER-WOLF et al. 2004; FÜRST 2004; HEALEY 2004). One conceptual way of understanding governance constellations is to regard them as collective action by private, public and corporate agents regarding public goods, spatially relevant resources, cultural values and action resources (HEAley 2006). The groups of players (decisionmakers) are usually represented by a triangular scheme, with state, economy and civil society on its three points forming collaborative strategies, handling unequal (spatial) resources.

When extending the disciplinary understanding of governance as it is mainly referred to in political science to an economic-cultural field, namely that of creative industries, the focus of attention is shifting: Applying the concept of governance to the economic sector, it becomes obvious that a multi-level as well as a multi-scalar perspective is of great importance (MORRISON 2007). While political scientists such as Benz and Fürst (BENZ 2004b; FÜRST 2004) have pointed to the complexity of democratically-oriented decision making, they have also acknowledged that a multi-level governance approach is mainly characterised by the changing relationships between stakeholders situated at different territorial levels, both from the public and the private sectors (see also MARKS 1993). When pointing to the decision-making processes aimed at increasing competitiveness and promoting regional economic fields such as creative industries, this understanding of governance mainly addresses strategies of negotiation-based approaches by rather new and less established agents in multilevel fields of actions.

Most existing steering measures for creative industries follow either a sectorial or a locational logic. The German administration on the federal level has only recently started to promote creative sectors in a top-down manner. Due to the newness of creative sectors for administrative policy making, generally speaking, policy approaches designed to promote the media and information and communication technologies (ICT) have simply been applied to the creative industries. By doing so, significant particularities that characterise the creative industries are often neglected (HESSE/LANGE 2012). This is especially relevant when looking at the following dimensions: the relevance of places, the internal market dynamics of creative industries, the network character of entrepreneurs in creative industries, as well as the potential for self-organisation of creative stakeholders (HESMONDhalgh/Pratt 2005; Pratt 2009). Two structural elements indicate the difficulties of steering creative industries. Firstly, the absence of suitable blueprints and 'ready-made concepts' for how to promote creative industries successfully; secondly, the novelty of these markets in combination with the spatial as well as cultural heterogeneity of creative sectors pose enormous uncertainty for professionals in public administration when investing public money in these markets.

In the economy-related governance debates, interacting stakeholders are mostly assumed to be stable and formalised, making policy modelling easier. However, in the case of policy making for creative industries, public administration is confronted with a broad range of mostly informal stakeholders. Therefore, transferring the same tools and strategies of established sectors such as cluster promotion in the automotive sector to the creative sectors is doomed to fail, due to the different levels of formalisation in the sectors. Based on this observation, scholars have detected the so-called globalisation paradox (DeFillipPI et al. 2007): The targeted creative professionals have to operate worldwide to make a living, whereas they depend on a reliable local context. The interaction cultures of the creative economies are reliant on local contexts, whilst at the same time the stakeholders in the creative economies are networked globally (see also GRABHER 2004). This structural paradox applies particularly to the software/games in- 
dustry (BMWi 2009b; Strambach 2010). This paradoxical basic structure, which Grabher has elucidated using the case of the project-based method of working in the software industry, poses a great challenge to practical policy direction and economic support.

\section{Consequences for understanding governance modes}

The arguments presented trace a basic line of our argument: In respect that we are, in analytical terms, confronted with understanding the internal logics of action among firms and freelancers within software and games industry on the one hand, and on the other we are aiming at better understanding the relationship to formal knowledge, administrative and service support structures that purport to help to improve regional competitiveness. Therefore, we consider the approaches of Kooiman as a valuable starting point for our discussion. His approaches conceptualise new forms of management or practices which are non-hierarchical, decentralised and organised within networks of different stakeholders as an expression of various forms of governance (KoOIMAN 1993; 2003). Three main modes of governance will help with the categorisation and discussion of existing and possible measures and steering approaches in the field of the software and games industry, which we will use as a heuristic instrument for our empirical section.

Self-governance: The term self-governance refers largely to forms of bottom-up self-organisation or networks with only marginal or no support by the public or the state. Informal and very often temporary networks are of special importance in the creative industries because ideas, prototypes, initial and unfinished products are first of all negotiated among friends and colleagues. Consequently, these networks function as testing arenas, where new products can be tested and experienced in a kind of non-economic laboratory situation. These networks can exist purely between companies, or they may also have the character of unofficial meetings such as round table meetings within the sector.

Co-governance: Co-governance denotes more institutionalised forms of cooperation in formalised networks. It refers to established interest groups, and in contrast to self-governance, these groups systematically represent the interests of their members. We include here for example in- dustry associations or networks which may also be supported by the state, but in which the state exerts no influence.

Hierarchical governance: Hierarchical governance refers to the traditional forms of top-down practices shared by the state, public administration and private sectors of creative industries. Besides infrastructure in the field of e.g. research and development and education we also include here cluster initiatives that are clearly initiated and guided by the state.

\section{Applied methodology and sites of analysis}

The following analysis of new governance approaches is part of two wider research projects: the comparative EU project ACRE and a project on creative knowledge workers in Munich. ${ }^{1}$ The methodology used in the following sections is a combination of interaction analysis (JACK et al. 2008) as well as policy analysis (BENZ 2004a; DAVIDE/Silvia 2008). For the present study, four industry experts and nineteen representatives from the field of administration were interviewed, and additionally a total of 56 semistructured, guided, topic-centred interviews were conducted with managers of the new media/games sector (41 in Munich; 15 in Leipzig). The selection of the interview partners was made by theoretical sampling, which means that the selection is based on definite and formalised criteria (LAMNEK 2005). The discussions were recorded, transcribed in full and anonymised. The analysis of the interviews is based on the principles of qualitative content analysis according to MAYRING (1995). The general aim of qualitative content analysis is to draw conclusions about certain aspects of communication and to enable a comparative analysis of the individual statements.

Munich and Leipzig offer two interesting case studies for comparison: Both cities are aiming to promote these types of industry and represent various governance approaches that aim to foster the city-regional competitiveness of these branches. The heterogeneity of these two cities is considered a valuable comparative point of departure for gaining in-depth insights to contribute to the overall research question, for several reasons. Firstly, regarding the geographical perspective, it is of major interest to understand how spatially oriented concepts of urban and 
regional governance (e.g. DAVIDE/Silvia 2008; FüRST 2004; Healey 2006; LANGe 2009) can contribute towards understanding successful or failed politically-motivated economic development approaches aiming at promoting new creative knowledge industries such as software and games industries. Secondly, although software/ games industries compete on a global market, significantly different historical paths, institutional contexts as well as regional developments have led to significantly different spatial and institutional patterns.

\section{Software and games industry - from a global to a regional sector perspective}

Whereas the software and games industry has assumed a central position internationally in the creative industries model for some time now, in Germany it is only very recently that it has been included as a regular part-market in the branch portfolio of the cultural and creative industries. The software and games industry includes the development and publishing of software products of all kinds, wherein in the subsequent examination a closer look will be taken in particular at the internet sector or new media sector - as a part-area of the broad field of software. ${ }^{2}$ The term new media refers to a combination of sound, text and images (moving or still), usually delivered in real time (PRATT 2007). It is used in this paper to refer to activities like web design, e-business, e-learning, e-publishing or other internet-related services. No reliable figures for the size of the sector and the number of people working in it can be obtained from the official statistics. The reason for this is, first of all, that official statistics are entirely absent, and secondly that it is hard to distinguish this sector from other originating sectors such as IT and software development or advertising (MAYER-AHUJA/ WOLF 2005). ${ }^{3}$ The new media sector is heavily concentrated in urban regions (BRACZYK et al. 1999).

Based on the German federal association G.A.M.E., the games industry includes for example computer games, console games, video games, mobile games and promotional games (BMWi 2010). Computer games are a complex and high-tech product, requiring sophisticated division of labour and numerous project partners for their production. Especially due to the development of new and more sophisticated generations of consoles, development costs have increased in recent years (MILES/GREEN 2008).

The industry can be roughly divided into two sectors: the developer side and the publisher side. The developer studios, or developers for short, design and produce the game. Only very few developer studios can bear the high entrepreneurial risk of games production independently, which is why generally they approach a publisher with a concept, or ally themselves firmly with one, in order to be financed by them. ${ }^{4}$ In Germany, the growth trend within the industry has until recently remained unbroken for several years. It is already the case today that entertainment software has long overtaken the box office takings of the film industry.

Germany is not, however, a pioneer country in the computer games industry. Games developers from the USA, Japan, Great Britain and Canada

Tab. 1: Statistical and structural indicators of the software and games industry in Germany

Statistical indicators Germany ${ }^{1}$

\begin{tabular}{|c|c|c|}
\hline \multicolumn{2}{|l|}{ Turnover in 2010} & $26.5 \mathrm{bn} €$ \\
\hline \multicolumn{2}{|c|}{ Turnover share in respect to cultural and creative Industries } & $17.2 \%$ \\
\hline \multicolumn{2}{|l|}{ Number of employees in Germany } & 252382 \\
\hline \multicolumn{2}{|l|}{ Number of firms } & 28527 \\
\hline \multicolumn{3}{|l|}{ Structural indicators $^{2}$} \\
\hline Typical figures for new product & \multicolumn{2}{|c|}{$\begin{array}{l}\text { Team size: } 30-50 \text { specialists; development time: } 2-3 \text { years; } \\
\text { Investment: over } 2 \mathrm{~m} € \text {, sometimes more than } 50 \mathrm{~m} €\end{array}$} \\
\hline Project team professions developers & \multicolumn{2}{|c|}{$\begin{array}{l}\text { Game designers, writers, graphics designers, modelers, animators, inter- } \\
\text { face designers, programmers, level designers, sound designers, composers }\end{array}$} \\
\hline Tasks performed by publishers & $\begin{array}{l}\text { Financing, product } \\
\text { distribution }\end{array}$ & dvertising, quality control, \\
\hline
\end{tabular}

Sources: 1 BMWi (Hrsg.) 2010; 2 WALZ/SEIBERT 2010 
are the ones who dominate the sector, and this applies also to the publisher area (WALZ/SEIBERT 2010). To date, the German developer sector has barely been able to push forward into the international market with its titles. For German developer studios, two factors are regarded as being decisive for breaking down barriers for developers in relation to multinational hardware and publishing enterprises (TEIPEN 2009): firstly the level of qualification and availability of employees, and secondly the financing of the high production costs. The development of digital games is costly and high-risk in economic terms. The market success of a new title is difficult to predict, and ultimately more than $95 \%$ of games fail on the market. Compared with other countries, the barely developed state of risk financing in Germany represents an obstacle.

\section{Comparing the software and games industry in Munich and Leipzig}

The structure of the software/games industry has obvious differences in Leipzig and Munich. This concerns the number of firms and employees, the GDP, as well as the "institutional thickness" (Amin/Thrift 1994) at the two locations. Nevertheless, both cities claim to have a significant role as a media hub, having their roots in the ear- ly 20th century. Leipzig is historically considered as a media centre that awaits a continuation of these historical assets. Bathelt in particular and others have pointed to the systemic friction and regional disjuncture of these branch-specific paths (BATHELT 2002, 2005; BATHELT/BOGGS 2003).

In contrast to Leipzig, Munich's development is more characterised by continuity than by rupture (BATHelt/Boggs 2003; von Streit et al. 2010a). Nowadays, the Munich region is considered to be one of the most important media centres in Germany, characterised by a broad media range and great functional diversity (BIEHLER et al. 2003; STRÄTER 1999). Furthermore, Munich's strong microelectronics industry, which had been the lead industry in the region for several decades in the 20th century (STERNBERG/TAMÁsY 1999), created the ground for a growth of sectors which are well connected with microelectronics, such as the IT sector, software and media (STENKE 2002), when the economic structure became more diversified from the 1990s onwards. Concerning the new media sector, the Munich region is the most important location for this sector in Germany, besides other media metropolises such as Berlin, Cologne, Hamburg, Düsseldorf and the Rhine-Main area (STRÄTER 1999; KRÄTKE 2002). Concerning the games industry

Tab. 2: Media, information technology (IT), and the software/games industry at Munich and Leipzig

\begin{tabular}{|c|c|c|}
\hline Indicator & Munich City/Region & Leipzig \\
\hline Inhabitants (2011) & City: 1378 176; Region: $2727106^{1}$ & City: $531809^{2}$ \\
\hline $\begin{array}{l}\text { Employees liable for social } \\
\text { security contributions }\end{array}$ & City: 709580 ; Region: $1178756^{1}$ & City: $177640^{2}$ \\
\hline \multicolumn{3}{|l|}{ Media } \\
\hline Employees & $\begin{array}{l}57000(2009)^{3} \\
\text { (liable for social security contributions only) }\end{array}$ & $8500(2009)^{4}$ \\
\hline Number of firms & $4666(2010, \text { Munich region })^{3}$ & $790(2009 \text {, City of Leipzig })^{4}$ \\
\hline \multicolumn{3}{|c|}{ Information and communication } \\
\hline Employees & $\begin{array}{l}54000(2009)^{35} \\
\text { (liable for social security contributions only) }\end{array}$ & $\begin{array}{l}10000 \text { employees and } \\
1000 \text { freelancers }(2009)^{4}\end{array}$ \\
\hline Number of enterprises & $9666(2010)^{35}$ & $743(2009)^{4}$ \\
\hline \multicolumn{3}{|l|}{$\overline{\text { Software/games industry }}{ }^{5}$} \\
\hline Employees & $14927(2010)^{67}$ & $1699(2007)^{8}$ \\
\hline Number of firms & $1798(2010)^{67}$ & $268(2007)^{8}$ \\
\hline
\end{tabular}

Sources/notes: 1 Bayerisches Landesamt für Statistik und Datenverarbeitung 2012; 2 Amt für Statistik und Wahlen/Stadt Leipzig, 31.11.2011; 3 IHK für München und Oberbayern/LH München, 2011; 4 Amt für Wirtschaftsförderung der Stadt Leipzig 2010; 5 includes software, data and IT services, e-commerce; 6 includes publishing of computer games, development of internet presentations and miscellaneous software development, web portals; 7 Europäische Metropolregion München e.V., 2012; 8 Amt für Kultur der Stadt Leipzig 2010 
in Munich, there are only around ten developer studios, most of them being relatively small. Munich carries greater weight as a location for games publishing: one of the well-known German publishers, Koch Media, employs around 300 people. Apart from that, Munich is home to branches of large international groups (VON STREIT et al. 2008).

Leipzig is the largest city in the state of Saxony, its population exceeding 500000 . When looking at the economic sector of the software and games industry in Leipzig, this is primarily known for its Games Convention (GC) trade fair, which ran until 2008. It is the biggest trade convention in Europe and the second largest worldwide. ${ }^{5}$ It was in the late 1990s that the German industry federation of games producers (Bundesverband Interaktive Unterhaltungssoftware - BIU) came up with the idea of a European convention to be held in Germany. In 2002 the Games Convention took place for the first time. It developed very well with strongly rising visitor numbers. Already in 2002, 80000 visitors came to see the first event; in 2005, with 134000 , nearly twice as many visitors as to the E3 convention held in the USA wanted to see the latest products of the software and games industry. Nevertheless, in 2009 the GC was moved to Cologne.

\section{Governance and steering modes in Munich and Leipzig}

The following section deals with the empirical analysis of existing support measures for the software and games sector in Munich and Leipzig. The aim here is to elucidate steering modes in these sectors with the aid of the three modes of governance that have already been explained (KoOIMAN 1993, 2003).

\section{Hierarchical governance and steering modes: Munich}

State-led technology and innovation policy have a long tradition in Bavaria. The dynamic development of Munich into a centre of modern high technology - to a 'Municon valley' - is also the result of technology policy measures of the federal and state governments (HÄUSSERMANN/ Siebel 1987; Castells/Hall 1994). Up to the present time, the state of Bavaria and the city of Munich have deployed an impressive variety of policies directed at improving entrepreneurship, commercialising knowledge and creating networks of innovation. The state of Bavaria is the more important stakeholder in the promotion of the creative knowledge industries in the $\mathrm{Mu}$ nich region. Its enduring economic development strategy can be characterised as top-down approaches which focus on innovation, knowledge and high-tech sectors (VON STREIT et al. 2010b). There were three main policy events, all led by the state of Bavaria, under which framework the media and software/games industry were also promoted: the Offensive Zukunft Bayern (future Bavaria initiative) (1994-99), the High-Tech Initiative (1999-2006), and the Cluster Initiative (2006 ongoing). The first two initiatives accounted together for about $4.251 \mathrm{~m} €$ (Bayerische Staatsregierung 2012). Although all state economic development programmes are directed at the entire territory of Bavaria, this activity disproportionately affects the region of Munich because of the spatial clustering of high-value activity in the metropolitan area. In the region of Munich the media and software industry was supported especially in the area of physical infrastructure (start-up centre, university buildings), training, research and development (R\&D), and support for start-ups by various initiatives.

Compared to the first two initiatives, the cluster initiative is both smaller and differently configured from the previous two initiatives $(66.6 \mathrm{~m} €$ for 2006 to 2015; StMWIVT 2012). It aims at building state-wide networks interlinking business and scientific potential in 19 defined clusters of industry and expertise (VON STREIT et al. 2010b). The media as well as the software/games industry have also been promoted by the cluster campaign up until the end of 2011. The cluster audio-visual media (CAM), to which approximately 300 companies and industry insiders belonged, had its base in Munich. The objective of the project was defined as increased networking between smaller firms and big players as well as the media and the games sector (VON STREIT et al. 2008). At the end of 2011, the Bavarian cabinet decided against continued funding of the cluster and dissolved it. According to the federal ministry, the cluster structure had proved not to be a suitable instrument for linking small firms and global players, since the cluster in particular did not reach the global players. It is planned to integrate the support for games into existing programmes, and to use existing contacts with partners and institutions better for games support.

Before the games sector had become part of the cluster for audio-visual media, Bavarian policy 
had paid no attention to the industry, either in respect of the special needs and problems of the sector in Germany and in the Munich region or in respect of the development of suitable support measures. According to one interview partner who was active in the cluster, the benefit of the cluster work was above all that the reputation of the sector has been generally improved. ${ }^{6}$ In particular, the games industry has the reputation of producing products that endanger children and young people. This also has a negative effect on the financing of projects by banks, amongst others. These image effects are judged by the interview partners to be far more important than for example the financial benefit through grants or subsidies or support aimed at formal networking. However, it is also emphasised that other cities in Germany such as Hamburg or Frankfurt recognised the potential of this sector earlier, and provide it with considerably more support than is the case in Munich.

Moreover, in the eyes of the developers, support that backs only the soft instrument of networking is not adequate. In their view, what is necessary for the development of the games sector in Munich is increased start-up subsidies or support programmes such as are usual in the film industry, in Bavaria e.g. by the FilmFernsehFonds Bayern GmbH (FFF), since games production is characterised either by high financial risk and a lack of bank backing, or by great dependence on oligopolistic publishing structures. Moreover, due to the global orientation of the sector, the Munich studios are competing with studios at locations which undertake much stronger top-down support with considerably greater financial means. Another major problem in the industry is the lack of qualified staff, which leads to developer studios competing for qualified staff and being in a sometimes ruinous competition for employees: "That is the main problem at the moment in the German industry. And the effect is that the industry is cannibalising itself - right now, and it is continuing to do so, since it is still booming and will continue to do so for years to come. The studios poach the best people from each other; this is a very strong competitive pressure, and there is simply a great lack of a rising generation." (Expert, New media/Games 1) The interview partners criticise the lack of interest, or inadequate interest, on the part of universities in the area of entertainment software: Courses that relate to the interface between creativity and computer science barely exist. "Real interaction between companies and the universities, such as exists in many other sectors, is still completely absent in the games sector." (Expert, Games) The lack of qualified staff as well as suitable training courses has only recently been taken into account by state officials, resulting in the newlyestablished "games engineering" course at the Technical University of Munich, which started in autumn 2011.

In the area of new media, there are no specific support measures provided by the state of Bavaria or the city of Munich. Only the selfemployed without employees have used state support which helped them on their path to selfemployment, either in the form of financial support or business start-up advice. What they miss is further training in the area of financing, marketing and distribution for start-up businesses. Mostly, the attitude of new media agencies to state interventions in their activities, whether it is through funding programmes, subsidies or the like, tends to be rather negative, as the following quotation shows: "I have had nothing whatever to do with the administration or politics so far; all these institutions, whether they are the chamber of commerce or trade associations or whatever, for us they are more likely to represent bureaucratic obstacles than something that would benefit us. We really don't have anything to do with them, nothing at all." (Management, New media / Games 2)

One industry expert explains this negative attitude by the fact that as a rule, the largely small and medium-sized firms in the new media sector incur extra bureaucratic work and additional costs when they are involved with government schemes, but these firms would seldom benefit from government measures. Furthermore, the firms do not expect state support: "We are used to the fact that nothing is done on the political side." (Management, New media/Games 8) The high cost of living in the region of Munich is seen as a negative location factor by both the new media agencies and the representatives of the games sector: "One thing that is definitely a great disadvantage of Munich as a location is the salary structures and the high cost of living." (Expert, New media/Games) In addition to the high cost of living, the high office rents in the Munich region are felt to be a disadvantage, as well as the fact that in Munich there is hardly any space available for small firms that are not yet established on the market. The same applies for studio premises: here too, there is not enough 
space available that is suitable for their location needs.

\section{Hierarchical governance and steering modes: Leipzig}

Regarding the role of the state in promoting creative industries, it is first and foremost of importance to mention the role of the media industry. It is embedded in a broad institutionalised knowledge and educational landscape, with various universities, polytechnic colleges, several extrauniversity research centres and various art, music and technical schools. Considerable federal and state financial investment represents traditional top-down planning modes that were aimed at targeting forward-looking fields of knowledge (mobility, R\&D, high-tech infrastructure, and communication technologies), and research outputs (e.g. numbers of patents, research funding) (LANGE et al. 2007). The city's policy objective was to steer new knowledge industries by acquiring state, federal or EU subsidies for establishing and accommodating these knowledge clusters. By founding new private but still state-led institutions to organise the promotion of clusters (e.g. Aufbauwerk $G m b H$ ), the city administration acted as a leading agent in a top-down manner. The statements of the majority of particularly the managers in the software/games industry who were questioned equate direct support with the term public support. Most of the interviewees did not receive any public support because there were no suitable state-funded (national/regional/ local) programmes for them, or because searching for appropriate information was considered to be too difficult and too time-consuming. Furthermore, the anticipated chance of receiving public support was considered too small, so the firms chose not to pursue public funding. "We would have been happy to receive it [government support] but the whole process was really frustrating for us." (Management, New media/Games 2) One manager was able to obtain support from the local job centre because before founding his business he had been unemployed. Generally it turned out that the software and games industry does not depend that much on public support as other sectors, such as the performing arts for example. But one can still hear calls for direct and indirect measures in practically every interview. The managers in general criticise a non-innovative support policy applied by the city - new branches or sectors are not taken into account; a time-consuming application process for support programmes; insufficient informa- tion. Their suggestions for improving the whole support system mention clearer information and easy access to support programmes. "... but the biggest problem seems to be getting information [about possible support programmes] ..." (Management, New media / Games 2)

Additionally, the interviewees suggest that the city should lower taxes for companies, establish platforms for the sector, and provide new support programmes for graduates and fairs, as well as offer affordable office space. One manager points out that the stakeholders themselves should become more active and should start changing the situation. At the same time, one manager calls for less regulation by the city so that the managers are freer to run their businesses. "For the firms it should really be easier." - "A lot of things would be much easier if the state didn't regulate so much." (Management, New media / Games 5)

These aspects made it clear that the managers still mention many aspects regarding existing support structures, which, in their opinion, need to be improved for the sector in Leipzig. Often they state that the city over-regulates and directs its efforts at the wrong aspects. They complain that there is a certain lack of knowledge on the part of the politicians, especially in terms of the role of the sector. One can see that the sector is segmented quite strongly; in many cases the managers questioned do not speak with one voice.

\section{Co-governance: Munich}

The Munich region hosts numerous formal network structures in the form of trade fairs, conferences, industry meetings etc. in the media and IT areas which can be described as co-governance modes. The new media sector in particular benefits from the co-location of Munich's media and IT cluster: according to the agencies, the numerous events help them to keep in touch with their clients. The two most important industry meetings are the annual Munich Media Days (Medientage München), which address media and new media subjects, as well as the annual Munich Gaming event, which addresses specifically the games industry.

Besides these formal network structures, the numerous venture capitalists represent additional important intermediaries. Their activity on the ground is a further building block for 
positive development, particularly of the new media sector in the Munich region. As studies show, a considerable portion of the nationwide investment by business angels accrues to the Munich region, with the new media and ICT being a preferred sector for investment (WALLISCH 2009). Munich is furthermore the most important location for capital investment companies in Germany (Klagge/Peter 2009). There is no formally organised industry association or federation in existence in the Munich region in either the new media sector or in the field of games. The Förderkreis Informations- und MedienWirtschaft München e.V. (FIWM) (support association for the information and media economy), which was established in 2000, represented an industry network for the new media sector. The association had up to 150 (mostly corporate) members and numerous working parties. The association ceased to exist in 2007, on account of lack of investment. According to one industry expert, those who were active in it could no longer sustain their activity for the association in addition to their paid work, which was usually self-employed. One interviewee from the municipal administration stressed that they thus lost an important contact partner who expressed the interests and needs of the industry.

In the case of new media, the statements made by both agencies and the self-employed about the benefits of formal, professional networks such as industry meetings that aim to intensify contact with other agencies and freelancers are contradictory. On the one hand, institutionalised exchange between agencies is rejected: "Associations and meetings - in my opinion they don't achieve anything. There is some benefit in the sense of meeting colleagues that maybe have the same problems, or else you can get to know freelancers for your pool of colleagues. But in general I don't think much of them, because the envy and competition between the agencies is too great to allow synergies to really come about." (Management, New media/Games 5)

On the other hand, self-employed people without employees use formal as well as informal industry meetings to exchange information about new developments in the sector, or for example to swap programs. Overall, the companies regard the formal contacts such as they make through associations, trade fairs and industry meetings as less important for the acquisition of work than the informal contacts to former colleagues and clients.

\section{Co-governance: Leipzig}

Regarding forms of co-governance, various networks, sector-related festivals and trade fairs of the software and games industry which have been established in the city of Leipzig come under consideration. They are considered a fruitful social context for e.g. addressing potential employees. Among others, one can find the Leipziger Informatik Verbund (LIV). This federation co-hosts the Leipziger Informatik-Tage (LIT), which represents a conference for the entire IT sector in Leipzig, a regular meeting for games developers and the Games Network LE. Since those seeking work in this field do not approach potential employers through formal intermediary structures, various network structures have an important function in initiating a job. Formal and informal networks are very important for the members of the sector, above all the informal ones. Particularly in the phase of establishing a business, they are important for gaining customers and staff. Even when the firms are more established and successful, they still use their informal network contacts. Formal networks, as previously mentioned, do exist and are partially used by the managers. Additionally, the stabilisation of business contacts within formal networks is considered to be difficult in many cases, because different competitors within a sector come together.

\section{Self-governance modes: Munich}

In the area of self-organised steering modes, informal contacts between market participants play the most important role both for the acquisition of work as well as for the recruitment of qualified staff. The new media companies describe the search for personnel through existing contacts to firms, agencies and universities as being more effective than through advertisements. Collaborators and freelancers are recruited above all through existing contacts as well as the firm's own home page. These freelancers come predominantly from the Munich region. "Over time of course we have built up a kind of pool. So say for example we need a writer, a photographer or a Flash programmer, we call them up and ask if they are available." (Management, New media / Games 3)

In order to minimise risks and uncertainties, the agencies prefer to work with self-employed people whom they already know, so that more stable project networks are formed out of project teams 
through repeated experience of working together. "Ideally we like to work with the same freelancers with whom we have already completed a project for the same client, because then we have a practised team, and that makes it economic and effective. The less familiar I am with the way a freelancer works, or with the work he produces, the more risky it is for the agency, and that can prove very expensive." (Management, New media/Games 3) Through the fact that the firms use known and tried-and-tested freelancers, they lend a certain stability to the relatively unstable and temporary organisation of the project work.

In order to assert themselves on the market, for both large and small agencies as well as the selfemployed without employees, belonging to networks plays an important role. Since access to the market in the new media sector is regulated to only a limited extent via certification, contacts to new clients come about mainly through recommendations and previous collaborations: thus trust, reputation and communication between the different protagonists play an important role in acquiring new business. Especially for the self-employed, being present on the ground, showing your face at informal industry meetings such as round tables, is regarded as an important factor for staying in business and maintaining a presence in the fast-changing labour market. In addition to brokering orders, these informal contacts are used for passing on information as well as for discussing professional problems. In the games industry, personal, informal contacts, especially to publishers, play an important role, as the publishers are the "customers" or clients and financial backers for the development of games. Personal, informal contacts are therefore of great importance in getting projects financed: "When it is a matter of pitching for some product or other, they [the publishers] only really talk to well-known firms. And the better they know one another, the greater the chances of being taken on. But that is always a bit of an old boys' club." (Management, New media / Games 4)

On the one hand, the spatial proximity to the many publishers who have their headquarters in Munich certainly represents an advantage for the Munich-based games developers. On the other hand, due to the dynamic development of the sector in recent years, the projects often extend beyond local and even national boundaries, so that the publishers the interviewees work with are often based in other European countries, Canada or the USA: "The computer games busi- ness is already an international business. At the moment $[\ldots]$ we are working primarily with German firms. But we frequently have discussions with international firms, who are primarily based in France, the UK, North America." (Management, New media / Games 4) Due to the manageable size, many of the developers know one another. These networks are linked more strongly to people than to a particular area. Ideas are exchanged spontaneously, meetings are arranged, and new orders and cooperative ventures are launched: "Well, they (the networks) are not very formalised. As I said, a few people will get together and say hey, let's start something off next month. (...)" (Management, New medial Games 4)

Furthermore, the extent to which developer studios are integrated into local networks is very varied, depending on their client structure. In particular, studios which produce exclusively for the foreign market hardly network at all locally: "They are based here in Munich too. And no doubt they are at the forefront too, but they are ones that do not network much. They just plough their own furrow, things go as they will, and they just don't need all that conference and networking rubbish." (Management, New media / Games 10) Purely local projects exist only on a limited scale, for example in the less staff-intensive and low-turnover area of children's games, casual games or browser games.

\section{Self-governance modes: Leipzig}

At this rather young location, which has only an underdeveloped and short history in the software and games industry, from the point of view of the firms based there, the availability of suitable employees is a prime issue. When acquiring new employees, the firms in the software and games industry that we have examined look for employees who have a degree with a focus on information technologies in general. But the managers whom we interviewed state that a lot of the universities, polytechnics and private schools do not work with modern and state-of-the-art software programs and tools, and that practical experience is underdeveloped in those starting out on their careers. Therefore potential employees need to show initiative and qualify themselves; additionally the managers are looking for creative employees who work independently. The firms we looked at employ between one and five people; alternatively, in many cases the managers can draw on several freelancers if necessary. 
This structure allows the companies to keep their fixed costs low and to realise more jobs. The costs for the recruitment and additional training of new employees are also relatively low because of the overall good formal education in the software and games industry in Leipzig. The opportunities for the companies to find talented employees are good. In many cases the managers have informal contacts to the universities and polytechnics because they studied there or they are working part-time as lecturers - this means that they have good access to potential employees. As already mentioned, the managers can use their informal contacts to the universities and polytechnics and former fellow students in order to gain customers, jobs and new employees. Finally, the managers appreciate the relatively low costs of living and culture in Leipzig.

\section{Characteristics and challenges of the two case studies}

The three types of governance have served as an organising principle to shed light on the high variability of modes of governance. The case of Munich shows the following:

1. The example of the cluster (CAM): The gain in image was rated more highly by the firms than the networking activity. The cluster was certainly used as a contact platform by small games studios, and it opened up for them access to the media economy. One important aspect is that through the cluster, the field of policy and administration gained knowledge about the potentials, working methods and needs of the industry. However, the cluster was not the appropriate instrument for forging links between small developer studios and big firms or global players. Two points are significant here: Firstly, global players have their own networks and are not reliant on support; and secondly, due to the specific characteristics of the games industry, even small developer studios have a global orientation and are not necessarily incorporated into local networks. Cluster support that is designed predominantly as a networking strategy does not seem, at a location like Munich, which already has a dense institutional environment and a high number of companies, to be a suitable instrument for moving a sector forward significantly. Furthermore, the most acute problems in the sector, such as the lack of qualified personnel and risk capital at the local level, can hardly be countered with support programmes which decisively back networking.
2. The dissolution of the new media network of the FIWM demonstrates the fragility of selforganised networks in the creative industries. When this network within the new media sector was dissolved, a body was lost which could represent the needs of the industry to the area of public administration. At the same time, the administration lacks an appropriate contact partner in the individual sectors of the creative industries, and thus also in many cases the knowledge and partners needed for developing an appropriate set of support instruments.

3. In the field of new media, the Munich region has developed to become a leading location in this sector, without there having been any special support measures, or ones tailored to the sub-market, forthcoming from the public sector. This shows that the strong institutional environment, the thick labour market, the availability of venture capital and the proximity to adjacent sectors as well as clients at the Munich location can compensate for a lack of sector-specific support, or may even render it unnecessary. In the field of games too, industry experts judge the prospects for this sector - irrespective of state support - to be positive, on account of the growing media convergence. Here, the strength of the location in the field of media and ICT plays an important role: for one thing, the games sector is an important constituent of the cross-media exploitation chain (e.g. in converting games licenses into films); and for another, as a driver of innovation, it penetrates into many areas of the media economy, IT industry or film and animation industry.

In the case of Leipzig, the following results can be presented:

1. Market participants regard the formal support structures set up by the national, federal and local authorities as rather inadequate. Particularly in the search for new employees, they increasingly rely on informal, nearby social networks of relationships that have been established personally, in order to generate workforce, freelancers or other sources of knowledge-based expertise. Since professional and formal network structures predominate in this sector to only a limited extent, market participants are forced to rely largely on these informal network relationships.

2. It has furthermore been shown that in its support programmes, local policy has taken only 
inadequate account of the contexts of such a fast-growing and globally-oriented trade fair format as the GC. The place of formalised network structures in Leipzig is taken in particular by personal relationship networks for settling urgent questions relating to knowledge transfer and the demand for labour.

3. The case of the Leipzig software and games industry shows first of all location-specific organisation and governance modes for this young location. Whilst on the one hand the GC games fair, which became internationally important within a short space of time, temporarily brought the sector forward at the location, on the other hand the time span for developing independently stable yet simultaneously formal market structures between firms, representative groups and educational and research establishments was too short. Similarly, success came too quickly to allow appropriate location conditions (e.g. hotels) to develop for larger trade fairs. The Games Convention rapidly grew to global importance and became a great success, as much for the company Leipziger Messe $\mathrm{GmbH}$ as for the local and (few) federal politicians involved and the representatives of the BIU. Even as early as this moment of success, it became clear that this trade fair concept lacks a thick institutionalised regional policy. Regarding the tremendous speed of the success of the fair, it was not possible to establish an adequate base that would legitimise hosting this global fair at Leipzig in the near future. The few larger regional companies and branches of global players (none of them in the immediate region of the city of Leipzig) and the few freelancers and micro-firms in games development did not legitimise this sufficiently. Leipzig's local politicians and the regional government of Saxony did not pay attention to linking the few local freelancers and small firms in the sector into the Games Convention properly, and to developing a more integrated thick institutionalised regional policy for the top trade fair event in order to link platform and production closer to the local and regional entrepreneurial stakeholders. The few local stakeholders in the new media sector are too small to participate (by exhibiting, giving presentations at professional forums, etc.). They therefore feel the Games Convention to be too abstract and large - in terms of serving only global players - for their needs. To sum up, it was neither possible to create an appropriate connection between the local economy and global platforms (e.g. trade fair), nor were the existing context factors, the local social networks among freelancers and entrepreneurs as well as the local support structures (IT-related service structures, educational centres or hotels etc.) strong enough to stabilise a rather fragile and young sector in the city of Leipzig.

4. The Leipzig example of the software and games industry shows how a missing connection between top-down policy strategies on the one hand and of small local industrial players on the other might lead to the failure of an originally successful idea. A closer networking of local freelancers and micro-firms and bigger companies from the broader region with the platform of the Games Convention probably could have helped to argue the case for the location. In addition, this large-scale convention shows a mismatch with the local structure and potential of the sector. From this perspective, the relocation of the global industry to Cologne as of 2009 offers the chance for a redefinition of the Games Convention label.

When comparing these two cases, it becomes obvious that time plays an important role: the strong market dynamics of the transnationallyoriented software/games sector stands in contrast to the more slowly-forming, democratically delineated administrative structures. The process of legitimisation of support measures within urban-regional scalar limits either lags behind the locationally flexible production networks of the industry, or it is difficult to implement in the first place, because of the existing dense network relations, e.g. in the form of cluster policies.

Furthermore, forms of co-governance are a means of taking account of cooperative forms of mutual programme development between the market and the state that has been neglected until now. Often it is precisely in young market structures that the public sector lacks clear contact partners. And it is apparent, particularly in more mature and advanced market locations, that those participating in the market are unclear about what benefits and effects a cluster policy, for example, might have for them.

\section{Concluding statements}

Generalising from the findings presented here, it becomes obvious that context-specific support structures must be developed, and that univer- 
salist governance approaches and fundamental assumptions appear to be not very expedient (BALDUCCI et al. 2004). Furthermore, due to the strong, technology-related dynamics specifically of this sub-market, there is a great lack of clarity for the administration with regard to what measures they can use to stimulate the market directly. Supporting the sector indirectly, e. g. by improving the education and further professional training on offer, or by offering premises, appears more beneficial here, even if this is of only limited effectiveness in respect of local-regional market activity (RIENIETs et al. 2009).

What would be an appropriate scale-sensitive governance frame? Only recently, many metropolises such as Hamburg (Kreativ Gesellschaft $\mathrm{mbH}$ ), Berlin (Projekt Zukunft) and North-Rhine Westphalia (Creative.NRW) have installed intermediary policy structures. Furthermore, Cologne's sector-oriented creative industries policies, for example, are the target of a comprehensive and integrated development strategy, pursued under the slogan "Economic support plus cultural policies plus city development policies". Within this strategy, overall city development is central, partly because adequate urban infrastructure is seen to be crucial for developing creative industries, and also because the state of North-Rhine Westphalia provides significant financial backing for such projects. In contrast to Leipzig and Munich, many metropolises around the globe have established agencies to support and coordinate the development of local creative industries. Create Hong Kong is a public agency with no less than 40 employees, Amsterdam has initiated Creative Cities Amsterdam Area (CCAA), a so-called "one-stop agency" run by eight employees, and Vienna has departure - an independent, public-private agency focusing on creative industries in the city region of Vienna, Hamburg has established the so-called Kreativ Gesellschaft, all negotiating as intermediaries between market practitioners and private sectors and public administration. Departure in Vienna is unique in its proactive approach, offering consulting and funding for young start-ups. Create Hong Kong is also responsible for marketing products and services of local creative industries abroad, whereas e.g. Melbourne focuses on infrastructural improvement, as well as on promoting (Asia-wide) and expanding education and training programmes for a growing creative labour market. In order to remain competitive, suitable governance structures are already established.

\section{Outlook: governance approaches that do or do not fit - the role of scales}

Based on these variations, we have summarised these empirical patterns in respect of geographical scales. The dimension of scales will now help us to elucidate steering practices that do, or do not, achieve a fit between the public and private sector. By structuring various forms of governance and comparing them in two cities, we wanted to shed light on two aspects: Firstly, the importance of acknowledging regionalised forms of formal and informal institutions that enable or block the growth of new sectors, in this case the software and games industry; secondly, the relevance of scale regarding the implementation of steering measures that aim at promoting rather young sectors. Munich has a thick regional institutional, educational, research environment, and all these agents and institutions serve, to a large extent, the emergence of rather new sectors. Due to the "institutional thickness", the implementation of cluster policies in Munich might only play a marginal role and have a minor effect in stimulating this sector. The strong international orientation even renders the implementation of a cluster policy obsolete, due to established strong international networks of the targeted agents.

In the case of Leipzig, despite its recent economic success, the city is still dealing with the effects and ruptures of the systemic change. Therefore, a rather informal social milieu of micro-entrepreneurs and just a few small and medium enterprises were able to set up appropriate steering governance structures. This happened in spite of the effects of an accelerated, footloose economy which, in the case of Leipzig, was able to raise the profile of that sub-sector (due to the unexpected success of the arrival of the international fair), but was unable to establish steering structures that were able to underpin this success within the city regions.

By taking into account the spatial aspects of governance, we were able not only to organise the various kinds of governance modes, but to shed light on their scalar dimensions. In doing so, it became obvious that especially informal social networks among managers and entrepreneurs first and foremost extend in a city-regional dimension. The dynamics of accelerated market dynamics have led to what DeFILLIPPI et al. (2007) have identified as one of the paradoxes of creative industries. According to them, the 
globalisation paradox - among others - plays a crucial role in the articulation of new production constellations as well as its steering practices: It generally addresses the ambivalence between locally-based creativity and transnational networks of production systems as well as localised production networks that are driven by an ethos of creativity and adhere to an "artistic mode of production". Although these two observed types, the cities of Leipzig and Munich, represent significantly contrasting situations and contexts, both cities and their policies struggle to overcome the same paradox. The Munich type declined to establish an economically, professionally and closely-connected powerful cluster management aiming at improving a rather positive economic performance market, because the location already had strong global links and important branches within a growing market. The negative side of this omission is that the public authorities now have no direct links in these markets and thus rather few opportunities to intervene should it be necessary. In short: the success of the Munich software and games industry and its institutional stability and thickness has led to the failure of a state-led cluster policy.

The Leipzig type also failed to establish appropriate steering structures when the quick and unexpected success of the Games Convention had raised the expectation that the city authorities should then provide measures that would - over time - lead to a similar thick institutional, educational and research-centred structure that would improve the stability of the rather unstable and fragile economic market situation at the Leipzig location. The short-term success of the sector at this location nevertheless could not be compensated and backed up by flexible state measures. The accelerated market dynamics have leapfrogged this location.

\section{Notes}

1 The EU-funded project "Accommodating Creative Knowledge - Competitiveness of European Metropolitan Regions within the Enlarged Union" (ACRE), which ran from 2006 to 2010, focused on the role of creative knowledge sectors for city development in 13 European metropolitan regions (MUSTERD 2010). The Munich project analysed the time-space practices of creative knowledge workers in the context of new practices of work and the blurring of professional and private life (VON STREIT 2011).

2 The classification of the branches of industry (WZ) used hitherto did not permit any distinction between software and games. It is only the 2008 classification that allows a more accurate and differentiated analysis of the individual part-areas.

3 With the new 2008 classification, nothing will change in this regard in the case of the internet sector.

4 Other types of games developer companies are the inhouse developer who is part of a video games publishing company and produces exclusively for that publisher, or studios that develop games without publisher support, so-called self-publishers. These types are producers of specialist or niche games as well as browser games that are played over the internet using a web browser (MILES/ GREEN 2008). The development of browser games is also less costly than that of games for personal computers or consoles.

5 Recently the German Federal Ministry of Economics and Technology rated the Games Convention as one of the leading conventions for the games industry. The ministry will therefore officially subsidise young German firms in the sector to present themselves at the convention (press release of Leipziger Messe, 25th April, 2008: http://www. leipziger-messe.de/LeMMon/PRESSE.NSF/html_newstickerger/).

6 All interviews took place while the cluster was still active.

\section{References}

Amin, A. / Thrift, N. (2001): Living in the global. In: Amin, A. / Thrift, N. (Eds.): Globalization, institutions, and regional development in Europe. Oxford, 1-22.

Amt für Kultur der Stadt Leipzig (Ed.) (2010): SWOT Analyse der Kreativwirtschaft in Leipzig im Rahmen des Projekts „Creative Cities (INTERREG IV B) 2010“ (author: B. Lange). Leipzig.

Amt für Wirtschaftsförderung der Stadt Leipzig (Ed.) (2010): Eine Studie zur Leipziger Medien- und Kreativwirtschaft 2010. Leipzig.

Balducci, A./ Kunzmann, K. R. / Sartorio, F. S. (2004): Towards creative city region governance in Italy and Germany. In: DISP, 158, 2-4.

Bayerische Staatsregierung (2012): Initiativen. München. Internet: https://www.bayern.de/High-Tech-Offensive-.1380/index.htm, 1.11.2012.

BIU (Bundesverband Interaktive Unterhaltungssoftware e.V.) (2010): Marktzahlen Computer- und Videospiele. Gesamtjahr 2009. Datenerhebung. Berlin.

Bathelt, H. (2002): The re-emergence of a media industry cluster in Leipzig. In: European Planning Studies, (10)5, 583-611.

Bathelt, H. (2005): Cluster relations in the media industry. Exploring the "distanced neighbour" paradox in Leipzig. In: Regional Studies, (39)1, 105-127.

Bathelt, H. / Boggs, J.S. (2003): Toward a reconceptualization of regional development paths. Is Leipzig's media cluster a continuation of or a rupture with the past? In: Economic Geography, (79)3, 265-294.

Benz, A. (2004a): Einleitung: Governance - Modebegriff oder nützliches sozialwissenschaftliches Konzept? In: 
Benz, A. (Hrsg.): Governance. Regieren in komplexen Regelsystemen: eine Einführung. Wiesbaden, 11-28.

BenZ, A. (2004b): Governance. Regieren in komplexen Regelsystemen: eine Einführung. Wiesbaden.

BenZ, A. / LÜTZ, S. / Schimank, U. / Simonis, G. (2007): Einleitung. In: Benz, A./ Lütz, S./ Schimank, U. (Hrsg.): Handbuch Governance. Theoretische Grundlagen und empirische Anwendungsfelder. Wiesbaden, 9-26.

Biehler, H. / Brake, K. / Ramschütz, E. (1994): Standort München. Sozioökonomische und räumliche Strukturen der Neo-Industrialisierung. München.

BMWi (Bundesministerium für Wirtschaft und Technologie) (2009a): Gesamtwirtschaftliche Perspektiven der Kulturund Kreativwirtschaft in Deutschland. Berlin.

BMWi (2009b): Initiative Kultur- und Kreativwirtschaft Branchenhearing Software/Games-Industrie. Berlin.

BMWi (2010): Monitoringbericht zur gesamtwirtschaftlichen Perspektiven der Kultur- und Kreativwirtschaft in Deutschland. Berlin.

BraczyK, H.-J./Fuchs, G./ Wolf, H.-G. (1999): Introduction. In: Braczyk, H.-J. / Fuchs, G. / Wolf, H.-G. (Eds.): Multimedia and regional economic restructuring. London, $1-11$.

Castells, M. / Hall, P. (1994): Technopoles of the worldthe making of 21st century industrial complexes. London/ New York.

CAves, R.E. (2001): Creative industries. Contracts between art and commerce. Cambridge.

Cooke, P. / Lazzeretti, L. (Eds.) (2008): Creative cities, cultural clusters and local economic development. Cheltenham.

Crevoisier, O. (2004): The innovative milieus approach. Toward a territorialized understanding of the economy? In: Economic Geography, (80)4, 367-380.

Davide, P. M. / Silvia, S. (2008): Linking learning with governance in networks and clusters. Key issues for analysis and policy. In: Entrepreneurship and regional development, (20)4, 387-408.

DeFillippi, R. / Grabher, G. / Jones, C. (2007): Introduction to paradoxes of creativity: managerial and organizational challenges in the cultural economy. In: Journal of Organizational Behavior, (28)5, 511-521.

Europäische Metropolregion München e.V. (2012): Kreative.Kultur.Kompetenz. Datenbericht zur Kultur- und Kreativwirtschaft in der Metropolregion München. München.

Fichter-Wolf, H. / JÄHNKE, P. / KNORR-SiEdOW, T. (2004): Governance Capacity für eine wissensbasierte Stadtentwicklung. In: Matthiesen,U. (Hrsg.): Stadtregion und Wissen: Analysen und Plädoyers für eine wissensbasierte Stadtpolitik. Wiesbaden, 309-336.

FIKIRKocA, A. (2007): Unravelling the paradoxes of the (new) digital economy. Myths and realities. In: Critical perspectives on international business, (3)4, 1742-2043.

FÜRST, D. (2004): Regional Governance. In: Benz, A. (Hrsg.): Governance. Regieren in komplexen Regelsystemen: eine Einführung. Wiesbaden, 45-64.

Galloway, S. / Dunlop, S. (2007): A critique of definitions of the cultural and creative industries in public policy. In: International Journal of Cultural Policy, (13)1, 17-31.
GRABHER, G. (2004): Temporary architectures of learning. Knowledge governance in project ecologies. In: Organization studies, (25)9, 1491-1514.

HAUNSCHILD, A. / EICKHOF, D. (2007): For art's sake! Artistic and economic logics in creative production. In: Journal of Organizational Behavior, (28)5, 523-538.

HäussermanN, H./Siebel, W. (1987): Neue Urbanität. Frankfurt am Main.

Healey, P. (2004): Creativity and urban governance. In: Policy Studies, (25)2, 87-102.

Healey, P. (2006): Transforming governance. Challenges of institutional adaptation and a new politics of space. In: European Planning Studies, (14)3, 299-320.

Hesmondhalgh, D. / BAKer, S. (2008): Creative work and emotional labour in the television industry. In: Theory, Culture and Society, (25)7-8, 97-118.

Hesmondhalgh, D. / Pratt, A. (2005): Cultural industries and cultural policy. In: International Journal of Cultural Policy, (11)1, 1-15.

Hesse, M./Lange, B. (2012): Paradoxes of the creative city. Contested territories and creative upgrading - the case of Berlin, Germany. In: Die Erde, (143)4, 241-261.

VAN HeuR, B. (2008): Networks of aesthetic production and the urban political economy. Berlin.

IHK für München und Oberbayern/LH München (2011): Location for information, communication and media $\mathrm{Mu}-$ nich 2010. Munich.

INDERGAARD, M. (2009): What to make of New York's new economy? The politics of the creative field. In: Urban studies, (46)5/6, 1063-1093.

JACK, S. / DodD, S.D. / Anderson, A.R. (2008): Change and the development of entrepreneurial networks over time: a processual perspective. In: Entrepreneurship \& Regional Development, (20)2, 125-159.

JESSOP, B. (1995): The regulation approach, governance and post-fordism. In: Economy and Society, (24)3, 307-333.

Klagge, B./ Peter, C. (2009): Wissensmanagement in Netzwerken unterschiedlicher Reichweite. Das Beispiel des Private Equity-Sektors in Deutschland. In: Zeitschrift für Wirtschaftsgeographie, (53)1-2, 69-88.

Koolman, J. (1993): Modern governance. New government-society interactions. London.

KoOIMAN, J. (2003): Governing as governance. London.

KRÄTKE, S. (2002): Medienstadt. Urbane Cluster und globale Zentren der Kulturproduktion. Opladen.

LAMNEK, S. (2005): Qualitative Sozialforschung. Weinheim/Basel.

LANGE, B. (2005): Landscapes of cultural scenes. Socio-spatial emplacement strategies of "Culturepreneurs" in Berlin. In: d'Hauteserre, A.-M. / Terkenli, T. S. (Eds.): Landscape of a new cultural economy of space. Dordrecht, 41-67.

Lange, B. (2007): Die Räume der Kreativszenen. Culturepreneurs und ihre Orte in Berlin. Bielefeld.

LANGE, B. (2009): Governance und Netzwerke in der Kreativwirtschaft. In: Lange, B./Kalandides, A. / STÖBER, B./ Wellmann, I. (Hrsg.): Governance der Kreativwirtschaft. Diagnosen und Handlungsoptionen. Bielefeld, 47-60. 
LANGe, B. / Burdack, J. / Manz, K. (2007): Creative Leipzig? Pathways to creative and knowledge-based regions. Amsterdam. (ACRE report 2.6).

Lange, B. / Kalandides, A./Wellmann, I. (2010): New urban governance approaches for knowledge-based industries in multiplicities. Comparing two cases of large innercity developments in Graz and Berlin. In: Journal of Place Management and Development, (3)1, 67-88.

MARKs, G. (1993): Structural policy and multi-level governance in the EC. In: Cafruny, A. / Rosenthal, G. (Eds.): The state of the European Community: The Maastricht Debate and Beyond. Boulder, 391-411.

MAYRING, P. 1995: Qualitative Inhaltsanalyse: Grundlagen und Techniken. Weinheim.

Mayer-Ahuja, N. / Wolf, H. (2005): Arbeit im Netz. Formen der Selbst- und Fremdbindung bei Internetdienstleistern. In: Mayer-Ahuja, N./Wolf, H. (Hrsg.): Entfesselte Arbeit - neue Bindungen. Grenzen der Entgrenzung in der Medien- und Kulturindustrie. Berlin, 61-108.

Miles, L. / GReEN, L. (2008): Hidden innovation in the creative industries. London. (NESTA research report)

MorRISON, T.H. (2007): Multiscalar governance and regional environmental management in Australia. In: Space and Polity, (11)3, 227-241.

NefF, G. / Wissinger, E. / Zukin, S. (2005): Entrepreneurial labour among cultural producers. "Cool" jobs in "hot" industries. In: Social Semiotics, (15)3, 307-334.

PRATT, A. (2007): The new economy, or the emperor's new clothes? In: Daniels, P. / Leyshon, A. / Bradshaw, M. / Beaverstock, J. (Eds): Geographies of the new economy. London, 71-86.

PRATT, A. (2009): The challenge of governance in the creative and cultural industries. In: Lange, B. / Kalandides, A. / Stöber, B./Wellmann, I. (Hrsg.): Governance der Kreativwirtschaft. Diagnosen und Handlungsoptionen. Bielefeld, 271-288.

Rieniets, T. / Sigler, J./ ChristiaAnse, K. (2009): Open city. Designing coexistence. Amsterdam.

Rhodes, R.A.W. (1996): The new governance. In: Political Studies, 64, 652-667.

ScotT, A.J. (2006): Entrepreneurship, innovation and industrial development. Geography and the creative field revisited. In: Small Business Economics, (26)1, 1-24.

SMWA (Sächsisches Ministerium für Wirtschaft und Arbeit) (Hrsg.) (2008): 1. Kulturwirtschaftsbericht für den Freistaat Sachsen. Dresden.
StenKe, G. (2002): Großunternehmen und innovative Milieus. Das Beispiel Siemens/München. Köln.

SternBerg, R. / TAMÁsy, C. (1999): Munich as Germany's No. 1 high-technology region. Empirical evidence, theoretical explanations and the role of small firm/large firm relationships. In: Regional Studies, (33) 4, 367-377.

StMWIVT (Bayerisches Staatsministerium für Wirtschaft, Infrastruktur, Verkehr und Technologie) (2012): ClusterOffensive Bayern. Vernetzung in 19 Kompetenzfeldern. München. Internet: http://www.cluster-bayern.de/themen/ cluster/, 1. 11.2012.

Strambach, S. (2010): Path dependency, path plasticity. The co-evolution of institutions and innovation: The German business software industry. In: Boschma, R. / Martin, R. (Eds.): Handbook of Evolutionary Economic Geography. London, 406-431.

StrÄter, D. (1999): Multimedia. Profiling and regional restructuring of Munich as an industrial location. In: Braczyk, H.-J./Fuchs, G./Wolf, H.-G. (Eds.): Multimedia and regional economic restructuring. London/New York, 155-182.

VON STREIT, A. (2011): Entgrenzter Alltag - Arbeiten ohne Grenzen? Das Internet und die raum-zeitlichen Organisationsstrategien von Wissensarbeitern. Bielefeld.

von Streit, A. / Axtner, M. / Buchwieser, S. / Hafner, S. / Heinritz, G. / Miosga, M. (2008): Requirements and demands of Munich's creative knowledge enterprises. The managers' view. Amsterdam. (ACRE report 6.2)

von Streit, A. / Bontje, M. / D'Agnese, E. (2010a): Stable trajectories towards the creative knowledge city? Amsterdam, Munich, Milan. In: Musterd, S. / Murie, A. (Eds.): Making competitive cities. London, 43-66.

von Streit, A./Montanari, G. / Popp, M./Hafner, S./ Heinritz, G. / Miosga, M. (2010b): Policies and strategies for the creative knowledge economy in the region of $\mathrm{Mu}$ nich. How to enhance the city's competitiveness. Amsterdam. (ACRE report 10.7)

TeIPEN, C. (2009): Weltmarkt mit Hürden. Wachstumsbarrieren behindern die Computerspielindustrie. In: WZB-Mitteilungen, 125, 21-23.

WALLISCH, M. (2009): Unternehmensfinanzierung durch Business Angels. Zur räumlichen Organisation des informellen Beteiligungskapitalmarktes in Deutschland. In: Zeitschrift für Wirtschaftsgeographie, (53)1-2, 1-19.

Walz, S. / SEIBERT, T. (2010): Analyse der Gamesbranchenstruktur in Baden-Württemberg. Stuttgart. (Auftragsstudie für die MFG Baden-Württemberg mbH) 